\title{
Strategic Marketing Practices and Environmental Perception of Customer Oriented Service in Nigeria Deposit Money Banks in Lagos State
}

\author{
Onu, Christopher A. (PhD) \\ Adegbola, E.A.(Mrs) \\ Department of Business Administration and Marketing, \\ Babcock University, Ilishan-Remo, Ogun State, Nigeria
}

Doi:10.19044/esj.2018.v14n28p292 URL:http://dx.doi.org/10.19044/esj.2018.v14n28p292

\begin{abstract}
This paper examines the nature and influence of the relationship between the bank's strategic marketing practices and its service and seeks to determine the importance of strategic marketing practices in explaining the environmental perception of customers oriented service delivery. The study location was at the five selected Deposit Money Banks in Lagos State, Nigeria. A descriptive research design employing a stratified and convenience sampling techniques selected $74 \%$ of the bank staff which were contacted using questionnaires. The data collected were analyzed using the SPSS software version 19.0. Correlation analysis was conducted to establish the nature of the relationship between the bank's strategic marketing practices and it customers oriented service delivery while regression analysis used to explain its influence on customers oriented service delivery. The finding showed that positive relationship exists between strategic marketing practices and customers oriented service delivery $(\mathrm{r}=0.749 ; \mathrm{Fcal}=123.859 ; \mathrm{p}<0.000)$. The researchers recommended that commercial banks should embrace strategic marketing by being focused to adapt to changes, marketing of assets and capabilities and marketing of innovation for the growth and survival of the industry.
\end{abstract}

Keywords: Strategic marketing practices, Strategic marketing environment, Customer service delivery, Competition, Banks

\section{INTRODUCTION}

Strategic Marketing (SM) is the process whereby individuals or organizations make certain decisions in relations to future results and methods in which they are to be achieved and estimated (Barney, 1991). Strategic marketing is a means by which an individual anticipate the future and develop the necessary procedures and operations to influence and achieve the 
objectives. It is regarded as one of the pillars of marketing practice. Strategic marketing assists managers in formulating, implementing, and evaluating cross functional decisions that will help organization to achieve its objectives. Woodward (2004) proposed that strategic marketing is the means by which managers and marketers anticipate the future and develop the essential plans or operations to achieve organizational goals and objectives. Bank marketing is the creation and delivery of services to satisfy the customers need at a profit to the bank (Ezeoha, 2005). This signifies that customers should be the focus in terms of corporate planning and the survival of banks and therefore, the relevance of marketing to the survival of banking services should be esteemed. Therefore, strategic marketing is inevitably a survival strategy among organizations (like the Nigerian banking sector) to enable it reap more benefits of recapitalization exercise in this dynamic environment.

It has been understood by earlier researches that marketing activities (or marketing mix) do not take place in a vacuum, but occur in dynamic environment. Therefore, every organization must confront an external marketing environment that is dynamic. Olarewaju \& Folarin (2012) investigated the impacts of external environment on organizational performance in the food and beverage industry in Nigeria. The outcome of the research revealed that the external business environment or macroenvironment (i.e. economic, technological, political, socio-cultural, legal, demographic, cultural factors, and so on) have impact on organizational efficiency and effectiveness. For an efficient strategic marketing, it is necessary to discover an optimum "fit" between the organizations and the environment before the development of effective strategies that is concerned with the environmental analysis, i.e., internal and external analysis of environment (Hooley, Greenley, Cadogan \& Fahy, 2005).

In Nigeria, banking was said to have started with the exclusion of marketing like in most developed countries (Ezeoha, 2005). He stated further that the activities were concentrated mainly on acceptance of deposits and lending. The industry was controlled by a few banks, and with a seller market, there was no need to spend scarce resources on marketing (Ezeoha, 2005). For the Nigerian banking industry to grow efficiently and be stable, the industry needed to be regulated as well as supervised by the regulatory authorities. This was to enable it to play an active role in the Nigerian economy at regional and global levels, enhanced efficiency, stability, and soundness of the system so as to be competent and competitive players in Africa and at world levels (Soludo, 2004). This initiative (i.e. restructuring through merger and acquisitions as a result of capital inadequacy) was surely confronted with some challenges of liberalization and globalization as a result of technological advancement (Oladejo \& Oladipupo, 2011). 
Moreover, for any bank to survive in this competitive environment there is the need to adopt effective strategic marketing in the marketing of its services to woo potential customers by satisfying their needs and wants. Corroborating with this view, Anabila \& Awunyo-Victor (2012) stated that banks should always reassess their business strategies to ensure survival as well as profitability in this dynamic environment. Initially, marketing was ignored in the banking operation (Akinyele, 2010). The reason was that competition was non-existence in the banking industry and as such, there was no need for aggressive marketing (Akinyele, 2010). Today, the trend has changed as a result of the competitive nature of the banking industry as a result of technological turbulence, marketing research, demand uncertainty, and deregulation. To meet up with these challenges it is vital for banks to have a holistic view of their stakeholders - customers, employees, and all other stakeholders in their decision making, so as to serve them efficiently in their marketing strategy. Additionally, Nigeria is one of the developing nations in the world; and as such, strategic marketing has a pivot role to play in the Nigerian economy, as well as the banking sector. Without engaging effective strategic marketing in the banking sector, there may be little progress in the Nigerian economy as well as in its banking operations. Therefore, the research emphasizes that it is through efficient strategic marketing efforts that a developing country like Nigeria can compete efficiently in its banking operations with advanced nations of the world. Furthermore, this research emphasizes that strategic marketing in the Nigerian banking sector empowers the management to achieve its marketing programs of merger and acquisition. Consequently, the study is to ascertain as to whether efficient customer service delivery in banking sector drives by the strategic marketing practices and adherence of banks to environmental factors impacted on customer oriented service in Nigeria.

\section{Objective of the study}

The objective of this study is to investigate influence of strategic marketing on environmental perception of customers' oriented service of deposit money banks in Nigeria.

\section{Research Hypothesis}

In order to achieve the objective of study, the following null hypothesis was stated: Strategic marketing practice does not significantly affect environmental perception of customers' oriented service. 


\section{LITERATURE REVIEW}

\subsubsection{Concept of Strategic Marketing}

A considerable amount of literature has been published on strategic marketing. Strategic marketing has evolved through interaction amongst marketing management, strategy and planning. Akinyele (2010) reports that newly invented strategic marketing displaced long range planning because of the growing discontinuity of the environment. Strategic marketing is as a set of determinations that guide or direct managers to reach their long term desired market positions (Ferrell and Lucas, 1989). Cohen (1988) adds here that managing a business involves anticipating and responding to changes that affect the market place so that decisions are made today that allow the business to be ready for tomorrow in such a way as avoid the threats and take advantage of the opportunities. Strategic marketing is crucial to an organization because it takes into consideration the fundamental changes in the environment, thus making organizations more proactive. Coping with the increasingly competitive environment has called on firms to rethink their marketing strategies (Pearce and Robinson, 2001).

In a related study, Barney (1991) defined strategic marketing as process whereby individuals or organizations make certain decisions in relations to future results and methods in which they are to be achieved and estimated. Osuagwu (2004) described strategic marketing as a disciplined effort to produce fundamental decisions and actions that shape and guide what an organization is, what it does, and why it does it, with a focus on the future. In this regard Wright (2005) postulated that strategic marketing is all-embracing, flexible and adaptable practice. Strategic Marketing demands that marketing managers ensure that the organization achieves a sustainable competitive advantage (Wright, 2005); hence, a structured approach to planning and strategy formulation is advocated.

Waweru (2011) expresses that strategic marketing strategically deals with the direction and scope of the long-term activities performed by the organization to obtain a competitive advantage. The organizations (i.e. money deposit banks) apply their resources within a changing environment to satisfy customer needs while meeting stakeholder expectations. This implies that strategic marketing serves as the requirement to develop a strategy to cope with competitors, identify market opportunities, develop and commercialize new products and services, allocate resources among marketing activities and design an appropriate organizational structure to ensure the performance desired is achieved. Organizations need to develop sound strategies that help to fully understand the landscape, ward off threats, and become more capable to meet changing conditions. Porter (1980) indicates that strategy enables businesses to position themselves in industries. Roger (1990) postulates that strategy is the first level of bringing vision to the present, and it allows for 
specific goals to be defined, driving concrete actions, and making the vision a reality. Lambert and Knemeyer (2004) advised that managers develop strategies to guide how an organization conducts its business and how it will achieve its objectives.

However, the foregoing definitions implied that strategic marketing is the managerial process that entails analysis, formulation, and evaluation of strategies that would enable an organization to achieve its goals by developing and maintaining strategic fit between its distinctive competencies against the threats arising from its environment (Abdalla, 2001). Strategic marketing allows an organization to be proactive (making things happen rather than waiting for things to happen), rather than reactive (response in shaping its own future). Firms that value the importance of marketing in their system became proactive and began to pull the strategic plans. Through strategic marketing, the strategy became favourable and helpful in generating the customer loyalty. The breakthrough actions of the organization will result not only in a superior market performance, but also in giving superior value to their consumers (Srinivasan and Lilien, 2005).

There are a wide range of strategic marketing practices that banks can implement. Such strategies include the identification of customers who are most interested in supporting their mission (market segmentation), ensuring an image is built that is attractive to those people (product positioning), the development of communication messages most attractive to these people (advertising) and communicating with them through channels these people regularly use (place). Consequently, marketing strategies and market orientation can significantly increase the effectiveness of commercial banks in achieving their corporate objectives. Kotler (1991) indicates that the ultimate objective of all marketing strategies is to influence audience or customers behaviour.

On the forces influencing strategic marketing practices, Waweru (2011), reports that several forces impact the strategic marketing decisions of a wide range of companies throughout the world. The forces are disruptive innovation, commoditization threats, value-driven segmentation, organizational change, and collaborative challenges. Among these forces, collaborative challenges have been the major challenges confronted by commercial banks in Nigeria since the 2005 banking consolidation or reform. Commercial banks in Nigeria have pursued collaborative strategy through merger and acquisitions and strategic alliance during financial sector reforms. However, Waweru (2011) indicated that these relationships are challenging to manage and sustain. It is really a challenging initiative especially among competitors. The researcher argued that the success record for strategic alliances has not been favourable, although companies continue to pursue these initiatives because of the advantages. Hence, overcoming collaborative 
challenges is a high-priority strategic marketing initiative for commercial banks in Nigeria.

\subsubsection{Strategic Marketing Environment}

The term marketing environment reflects factors external to the business unit (opportunities available) and factors internal to the business (ability to exploit opportunities). These dimensions represent key aspects of both the external and internal environment for strategic marketing decisions. The use of external-internal environmental framework in the marketing literature was initially proposed by Jaworski (1988), and subsequently developed and applied by a number of authors such as Gardner et al (2000), Cavusgil \& Zou (1994) \& Koh (1991). Jaworski (1988) describes the environment as the general context or situation surrounding the firm. Jaworski (1988) identifies the external environment an abstraction of social, political, technological, and economic conditions) and the internal environment (referring to the firm itself) as two relevant constructs in the study of organizations.

In this paper and for banking industry in Nigeria, an appropriate model is one that facilities a rigorous analysis of internal organizational strengths and weaknesses as well as integrates the critical impact of external environmental factors. Specifically, while examining variance in firm performance, there is need to examine (1) the variance attributable to conditions in the industry in which firms operate and the observable/tangible competitive strategies such as product market strategies and the level of marketing programme implementation a firm employs, and (2) the factors external and internal to a firm. Hofer (1983) \& Hambrick (1983a) recommended on the need that a company can adapt a firm's marketing strategies to environmental conditions in such way which will produce a better performance from the environment. Higher levels of fit lead to higher levels of performance. Gichuki \& Ogollah (2014) present empirical research on the factors influencing the choice of marketing strategies of commercial banks in Kenya. They investigated both strategies adopted by commercial banks in Kenya and the factors influencing their choice of marketing strategy. Their results show that banking industry demands for continuous development and implementation of innovation strategies such as product, technology and service quality strategies. These strategies influenced choice of marketing strategy to a large extent by commercial banks.

\subsection{Strategic Marketing and Customer Oriented Service}

The rationale for strategic marketing is to accomplish stipulated objectives that can be assessed in the areas of asset quality, market share, profitability, management of departmental crisis, capital employed, liquidity, 
quality of marketing management, marketing cost, turnover of marketing staff, and gross earnings.

In the recent past, delivery high quality service is very crucial strategy of most business organizations (including banking sector) as means of responding to success and survival in today's turbulent environment (Ulwick \& Buttencourt, 2008 and Kheng, Mahamad, Ramayah \& Mosahab (2010). Asubonteng, McCleary \& Swan (1996) defined service quality as "the difference between customers' expectations for service performance prior to the service encounter and their perceptions of service received" (p.64). This view is similar to that expressed by Swati (2013) that service quality is an evaluation of how a performed service meets customers' expectations.

Assessing service quality and achieving the excellence in service deliveries have been the core strategies used by companies to achieve competitive advantage (Freitas \& Costa, 2012). Ehigie (2006) carried out a research on correlates of customer loyalty to their banks on Nigerian banking sector. The research was to discover how perceived quality of service or product, customers' expectations, and customers' satisfaction brought about loyalty in Nigerian banking sector. The outcome of the research showed that it is necessary to understand consumer behavior as the best way for keeping their realized customers and possibly get new ones. Thus, identifying both potential and realized customers' satisfactions assist in improving customers' loyalty and serve as means of differentiating one's service from those of competitors. In the same vein, Swar \& Sahoo (2012) conducted a study to determine an effective service delivery a case study of selected public, private, and foreign sector banks in Odisa, India. The result of the research revealed that to improve customer effective service delivery in the banking industry, it is vital for the management to have regular discussions with their workers and assess their experiences in their various assignments.

Botha \& Vanrensburg (2010) on their part came up with their understanding that the relationship between customers and organizations deals with trust as well as commitment that will result to greater customer retention, and increased organizational performance. Likewise, Oke, Adjei \& Osarenkhie (2013) investigated the role that service quality played in Ghanian banking industry as well as its effects on service delivery. However, the study revealed that where a gap exists between customers/consumers expectation and perception of service delivery was perceived as low and which amounted to customers' dissatisfactions. The study upheld that service quality is vital but insufficient yardstick for maintaining good relationship with organizational customers. Therefore, bank branches must be made accessible and responsive to customers' needs and wants 24 hours and seven days in a week ensuring that ATMs are reliable to improve customers' service deliveries. 
In evaluating service quality in an organization, Parasuraman, Zeithaml \& Berry (1988) developed SERVQUAL model having five dimensions, namely: tangibles (equipment, physical facilities, staff appearance), reliability (ability to perform the promised service dependably and accurately), responsiveness (willingness to help customers and provide prompt service), assurance (ability to instill trust and confidence to firm's customers), and empathy (caring of customers i.e., an individualized attention that a firm provides to its customers).

This implies that the bank should have modern equipment, physical facilities, and staff appearances should be paramount (i.e. tangibles). Also there is a need for banks to give interest in handling problems of customers, provision of service at stipulated time as well as maintaining error free records (i.e. reliability). In addition, banks should be desirous to assist customers, quick service, and informing customers the time service will be performed (i.e. responsiveness). Customers should feel free to transact with bank, bank is careful with customers, individual attention, and employees' attitude give confidence to customers and employees are knowledgeable in responding to customers' questions (i.e. assurance). Banks gives individual attention on time convenient to customers, personal attention as well as interest needs i.e., empathy (Agus, Bakers, \& Kandampully, 2007; Glaveli, Petridou, Liassides \& Spathis, 2006).

Furthermore, on the utilization of information technology (IT), Ehikhamenor (2003) stated that in the past banks in advanced nations have been committing much fund in acquisition of IT as a way of cost reductions and to better undertaken functions. Globalization has brought stiff competition in the financial services sector. This competition may likely yield the best in the financial sectors. To withstand competitiveness, the banking sector is required to be dynamic to react in response with recent products in the dynamic market requirements so as to meet the challenge posed by the increasing needs of customers. Kumar, Malathy, \& Ganesh (2011) and Munusamy, Chelliah \& Mun, (2010) investigated the diffusion of technology in developing countries, specifically in India, and found that technology has been very slow in banking sector in customer service deliveries.

The utilization of IT has brought about growth in service industries today and it is vital to employ IT in strategic business objectives of an organization (Durand \& Bouzidi, 2008). The clearest instance for the utilization of IT that brought the growth of a firm is the banking sector, where due to IT products in information exchanges, Internet banking, security investments, and electronic payments banks can offer various services to their customers with less human resource (Aremu, Majabi, Gbadeyan, 2011). Ogunleye (1999) stated that (1) the formal embracing of Information technology has facilitated chosen banks efficiency in Nigeria by making it 
more result-oriented and effective, (2) Information technology also has a great impact on the general banking outcome by making employees performance more effective and efficiency, (3) embracing information has intensified the hypothetical force of the banks. This is achieved through bank charges cheque withdrawal slip and withdrawal charges, (4) information technology has enhanced the bank customer relationship by offering effective services delivery in the whole week. Presently, customers in Nigeria are capable of reaching their account anytime of the day even after they have closed from their work to withdraw money to carter for their pressing needs and wants.

\subsection{Theoretical Framework}

A theory is a set of interrelated construct (concepts), definitions and propositions that presents a systematic view of phenomenon by specifying relations among variables with the purpose of explaining, predicting and controlling the phenomena. A variable is a construct or concept to which numerical values can be assigned (Folarin, 2000). Variables are generally used in psychology experiments to determine if changes to one thing result to changes in another (Kothari, 2004). A theoretical framework on the other hand refers to how the researcher or writer of the report not only questions, but ponders and develops thoughts or theories on what the possible answers could be, then these thoughts and theories are grouped together into themes that frame the subject (Gichuki \& Ogollah, 2014; Neuman, 2000). It is the process of identifying a core set of connectors within a topic and showing how they fit together. This study will be guided by a number of theories as discussed subsequently.

\section{Rogers Innovation Diffusion Theory}

The Rogers' Diffusion of Innovation Theory explain how adoption to new ideas is made as well as innovations by suggesting in the theory, five innovation attributes through which adoption is effected, which are: "observability, compatibility, trial ability, relative advantage and complexity" (Rogers, 1995). An attribute is said to have a relative advantage when the new innovations is seen to be better than the previous idea that it is replacing. Rogers' theory emphasizes that it is easier to implement innovations that show an improved advantage over that which was there before, making it easier to adopt. Greenhalgh (2004) adds that users would not adopt innovations that they did not see any relative advantage in. The ability of an innovation to be easily adopted is that it has to be compatible with a previous idea, meet their experience in the past and fulfill existing values, meaning that there is a higher chance for an innovation to be adopted if it is more compatible. This theory is relevant in explaining customer's decision to join a bank and to stay with the bank. Joining a bank is a result of visibility of innovation and eventually 
realizing positive outcomes of adopting the innovation. The findings confirmed this allegation by pointing out that innovation was the most significant factor influencing choice of marketing in the Commercial banks.

\section{Contingency Theory}

The contingency theory was propounded by Kast and Rosenzweig (1985) to the study of commercial banks strategic plans to curb competition. The theory states that an organization consists of various interdependent subsystems in which each subsystem has its own function to perform for the achievement of organizational goals and objectives. This could be regarded as quality of customer service, employee motivation, marketing strategy and technology which could be used as strategic response to competition in the banking industry. The human subsystem could be regarded as individuals in the organization in the areas of motivation and leadership. The contingency theory opined that each individual in the organization should be interdependent with each other so as to meet up with what is obtainable in the environment in which the organization finds itself as well as wider environment (Mentzer, 2001).

\section{Service Delivery Model}

Parasuraman, Zeithaml \& Berry (1988) developed the SERVQUAL model. It was initially made up of ten areas of service delivery, namely, courtesy, understanding the customer, competence, reliability, security, responsiveness, tangibles, communication, access and communication. The model assesses the gap between experience and expectations. Later on, the authors simplified the model with the acronym RATER: Reliability, Assurance, Tangibles, Empathy, and Responsiveness. This simplified model has been used extensively by service delivery firms or organizations because is regarded as being simple for bridging the gap between perceived and expected service delivery. Parasuraman et al.'s (1988) defines five gaps or discrepancies which may impinge on service quality also known as SERVQUAL model. According to Parasuraman et al. (1988), there are five gaps that organizations are expected to address in this model:

Gap 1 deals with the issue of what customers expect from product or service delivery as well as what managers think they expect from product or service delivery - survey research is the only means for bridging this gap.

Gap 2 deals with the issue of management perception of product or service delivery as well as the actual specification of the customer experience of product or service delivery - managers should make sure that their organizations fulfill their obligations by providing the necessary services they believe are needed by the customers. 
Gap 3 deals with the gap of experience specification to the actual delivery of such an experience. Managers are expected to evaluate the present customers' experience they render to know if they meet up to the expectation.

Gap 4 deals with the gap of delivery of the customer experience as well as what is communicated to customers. Sometimes organizations exaggerate the kind of goods or services that would be provided to their customers and thus, raising customers' expectations and harming customers' perceptions when they fail in their promises.

Finally, Gap 5 deals with the gap of customer's perception of the experience as well as the customer's expectation of the service delivery. Customers' expectations consists of their own past experiences, their personal needs as well as their own word of mouth.

Social Exchange Theory

Social exchange theory posits that the relationship between individuals in an organization is based on exchange of material, non-material as well as goods and services (Farganis, 2011). Therefore, Mentor's and mentee's actions or behaviours are based on perceived benefits and costs in the relationship of the participants. Also, according to Thibaut \& Kelley (1959) the reasons people participate in a social exchange are as a result of: expected reciprocity; anticipated profit in reputation and influence on others; altruism, perception of efficacy and direct reward.

In summary, the relationship between the theories discussed above is depicted with the framework below. The framework portrays that strategic marketing is an important tool driven by diverse theories that will help commercial banks in Nigeria achieve their overall goals while maintaining a strategic fit with their resources and the environment.

Figure 1: Theoretical Framework of strategic marketing practices in Nigerian banking industry

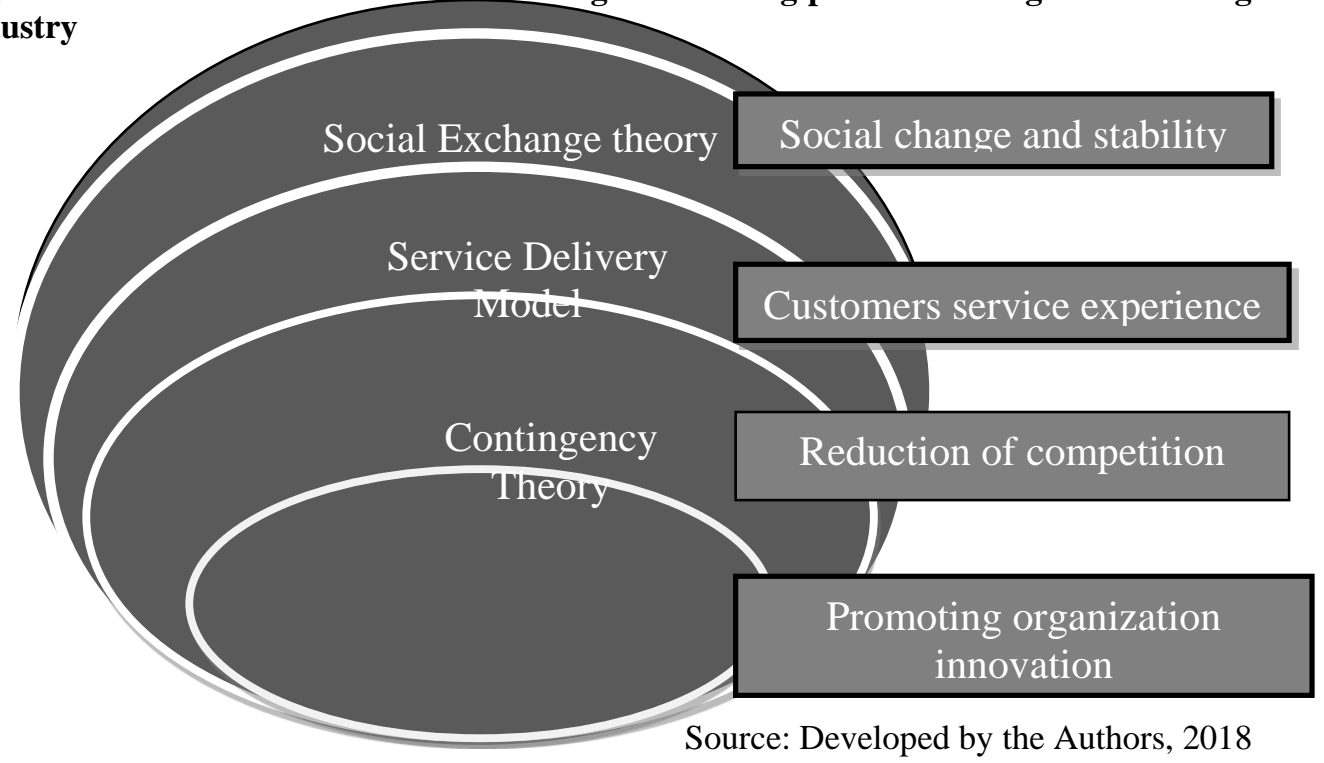




\section{AUDITORS' ROLES IN NIGERIAN DEPOSIT MONEY BANKS}

Strategic marketing practices and customer service delivery will operate efficient and effectively in an environment where fraud control is reduced to a very minimum and Audit committee responsibilities adhere to the international accepted ethical and legal standard.

Olatunji and Adekola (2017) observed that fraud has been a matter of concern all over the world. They asserted fraud that occurred in worldcom, Eron and others in the past. Adekola and Olatunji (2017) cited Fatoki (2015) that fraud in Nigerian banking sector in the recent past resulted as a collaboration between the banking employees and management leading to loss of huge sum of money and distressed of most of the banks. They stated that auditors activities in the areas of detecting, respond, monitor and prevent should be improved so that Nigerian banks will adhere to the internal control system obtainable in developed nations of the world.

Also, study was carried out to discover if Audit committee whose responsibility is to work with the internal auditors and management of deposit money banks in Nigeria actually influence the financial reporting of these banks (Onyabe, Okparachi, Nyo, Yahaya \& Ahmed, 2018). The study revealed that audit committee characteristics do not have effect on financial reporting of the chosen Nigerian banks. They recommended that the roles of audit committees in their respective banks in Nigeria should be strengthen in their financial reporting to comply with the international accepted ethics and legal standards guiding the banking sector.

Strategic marketing practices and customer service delivery will operate efficient and effectively in an environment where fraud control is reduced to a very minimum and Audit committee responsibilities adhere to the international accepted ethical and legal standard. This will make the banking sector by being focused to adapt to changes, marketing of assets and capabilities and marketing of innovation for the growth and survival of the industry and better customer service delivery.

\section{METHODOLOGY \\ Research design}

The research used descriptive survey to establish the relationship between strategic marketing practice and environmental perception of customers' oriented service of commercial banks in Nigeria. Descriptive research is the most commonly used and the basic reason for carrying out descriptive research is to identify the cause of something that is happening (Auka and Keraro, 2014). Descriptive research studies are designed to obtain important information concerning the status of phenomena from which valid conclusions may be drawn. 


\section{Study population}

The study population comprised of the staff in corporate planning department, commercial department, and marketing department of the five (5) sampled banks as sourced by the researcher from the human resources department showed that: First Bank (33 staff), Zenith Bank (31 staff), Guaranty Trust Bank (27 staff), United Bank for Africa (26 staff) and Wema Bank (21 staff) (Human resources department-First Bank, Zenith Bank, Guaranty Trust Bank, UBA \& Wema Bank, 2013). Therefore, the total population of the three departments of the five banks highlighted above is 134 .

\section{Sample size}

A sample size of 100 (20 to each bank) staff were selected using stratified sampling and convenience sampling techniques. The basis for chosen 20 samples each from the five selected banks is to ensure equal representation. The researchers were interested in observing what was happening at corporate planning department, commercial department, and marketing department of the selected banks and without any attempt to manipulate or control it. Also the researchers used convenience sampling. The respondents were selected based on willingness to participate in the sample. A single-stage sampling procedure was used by the researcher, through the assistance of the Human resources departments of the selected banks; the questionnaires were administered to the respondents in their respective banks.

\section{Data collection instruments and administration}

A questionnaire was used to collect data. Using a questionnaire is advantageous since it presents an even stimulus potential to large number of people simultaneously and provides on investigation with easy accumulation of data. The questionnaire was administered to the respondents at the head office of the selected Nigerian banks based in Lagos. A time period of one week was allowed to fill the questionnaire after which they were collected.

\section{Validity and reliability of the instrument}

The validity of questionnaire was evaluated by experts in banking to ensure that the developed questionnaires had included all the important questions needed to facilitate excellent study about strategic marketing quantitative study in the Nigerian banking industry. According to Brown et al. (1992), validity of an instrument is better improved by expert judgments. The validity evaluated include; construct validity which refers to the extent to which operationalization of construct do actually measure what the theory say they do, content validity which is an assessment of the test content to discover if it comprises of a representative sample of the behaviour domain to be assessed and face validity which is an estimate of whether a test appears to 
measure a certain criterion that is whether a test appear to be a good measure or not (Trochim, 2006).

The reliability of the instruments was tested using the Cronbach Alpha Coefficient. Cronbach alpha coefficient was the most popular test of inter-item consistency reliability (Aliyu \& Rosli, 2014). After running the data using SPSS version 22 for windows, it was found that the measures possess a high reliability standard of 0.956 and 0.957 . The Cronbach`s alpha coefficients of the factors/constructs surpassed the 0.70 threshold recommended by Nunnally (1978), for the test of scale reliability. The questionnaire was pilot tested with two commercial banks purposefully selected in Ogun State to test for the instrument is reliability.

\section{Data presentation methods}

Data was presented by use of tables, frequencies and percentages. This gives a clear data that shows the impact of strategic marketing practices on environmental perception of customers' oriented service customer oriented service of commercial banks in Lagos State.

\section{Data analysis}

Preliminary data analysis were edited, appropriately coded, the data files checked and re-checked to minimize data entry errors and detect out-of-range values that were rectified and then entered in the statistical package for social science. The analysis was facilitated by SPSS version 19.0 which was available for the study. The data was analyzed using descriptive statistics such as percentages, mean, frequency, and cross tabulation. Correlation and regression analysis were used to test the hypothesis. The Correlation was used to determine the relationship between the strategic marketing practices and environmental perception of customers' oriented service variables while regression analysis was used to determine the level of contribution of each of the types of strategic marketing on customer service delivery.

$$
\mathrm{Y}=\beta_{0}+\beta_{1} \mathrm{SMP}+\varepsilon
$$

Where:

$\mathrm{Y}$ is environmental perception of customers' oriented service delivery (dependent variable).

SMP is strategic marketing practices (independent variable) likely to bring about is customer oriented service delivery

$\epsilon$ is the error term, other factors that influence is customer oriented service delivery. 


\section{RESULTS OF THE STUDY}

Demographic Profile of the Respondents

The results indicate that $60 \%$ of the respondents were male while a sizeable percentage of $40 \%$ were female. Majority (51\%) of the respondents fall under the age group categories of 31-40 years while only $14 \%$ were between 40 to 50 years, which could mean that majority of the respondents in the sampled commercial banks are in their middle ages and this age usually constitute the vibrant cream of the workforce in the private organizations. With regard to educational qualification, majority $(52 \%)$ of the respondents had attained masters degree, followed by bachelor degree (39\%), 3\% had doctorate degree, $6 \%$ had professional qualification while only $1 \%$ had other qualifications. This could mean that most of them have attained secondary degree in relevant qualifications to help analyze issues.

In respect of departments wherein respondents are working at the time of survey, the largest number (40\%) of respondents work in marketing department, followed by commercial department (30\%), $18 \%$ of respondents work in functional areas other than marketing, commercial, and corporate planning departments while $12 \%$ of the respondents' works in corporate planning department. It could be deduced from the data analyzed above that the marketing department and commercial credit departments have the higher number of staff as such the bank will always strive to gain the larger share of market share. The employment status indicate that, majority (44\%) of the respondents worked as lower managers, followed by respondents who are middle managers (38\%) and top managers accounted for $16 \%$ while other options made available in the question attracted only $2 \%$.

With regard to the duration of employment, $92 \%$ of the respondents had worked in the commercial banks for a period of 5 years and above which implies the respondents have considerable experience in their fields that will enable them to have a good knowledge of strategic marketing practices of commercial banks.

\section{Correlation Analysis}

This was conducted to establish relationship between strategic marketing practices and environmental perceptions of customer oriented service delivery of the selected Nigerian bank. The coefficient of correlation (r), determine the degree (strength) of relationship and its value is between -1 and 1. A value 0 implied no relationship, 1 implied a perfect positive relationship, -1 means a negative relationship. An absolute value of $r$ between 0.5 and less than 1 implied a strong relationship between the variables. If the value $r$ is greater than 0.3 and less than 0.5 then the relationship is moderate. The relationship is weak if the value of $r$ is less than 0.3 . 
Table 4.1 Correlation

\begin{tabular}{cccccc}
\hline Variables & Freq. & Mean & SD & R & Sig. \\
\hline $\begin{array}{c}\text { Strategic marketing practices } \\
\begin{array}{c}\text { Environmental perceptions of customer's } \\
\text { service delivery }\end{array}\end{array}$ & 100 & 28.5226 & 1.09862 & .749 & .000 \\
\hline Total & 23.4355 & 3.19386 & & \\
\hline & 200 & & & & \\
\hline
\end{tabular}

The correlation revealed that there is a positive significant relationship between the strategic marketing practices and environmental perceptions of customer's service delivery of the selected banks at $r=0.749,198$ degrees of freedom and $<0.05$ significant level. This finding indicates that environmental perceptions of customer's service delivery are positively correlated to strategic marketing practices.

\section{Regression Analysis}

Regression was used to obtain an equation which describes the dependent variable in terms of the independent variable based on the regression model. It shows regression analysis of strategic marketing practices against environmental perceptions of customer's service delivery. The researcher proposed that a bank undertaking strategic marketing practices tends to grow faster than a bank that does not practice it. The SPSS program was employed to analyze and found the coefficient of correlation (R) and coefficient of determination $\left(\mathrm{R}^{2}\right)$. The result is presented in Table 4.2.

$$
\text { Table 4.2 Regression Coefficients }
$$

\begin{tabular}{cccc}
\hline Variables & Coefficients & Standard Error & Significant \\
\hline (Constant) & 0.568 & 0.319 & 0.078 \\
SM Practices & 0.792 & 0.071 & 0.000 \\
\hline
\end{tabular}

$\mathrm{R}=0.749, \mathrm{R}^{2}=0.561$, Adjusted $\mathrm{R}^{2}=0.556$, t. cal $=11.129$, t. tab $=1.98 \mathrm{~F}_{(1,97)}=123.859, \mathrm{~F}$. $\mathrm{tab}=3.84$

Table 4.2 shows that the relationship between strategic marketing practices and environmental perception on customer-oriented service is positive and high $(\mathrm{r}=0.749)$. The calculated co-efficient of determination is denoted by $\mathrm{R}^{2}(0.561)$ indicates that 56.1 percent of the variation that occurs in environmental perception on customer oriented-service can be explained by relating it to the strategic marketing practices of the banks. In other words, $43.9 \%$ of the variation that is below 0.5 may not be explained by its relationship with the strategic marketing practice variables; with such high percentage of 56.1 percent, there is a strong indication that strategic marketing practices influenced environmental perception on customer-oriented service of chosen Nigerian banks. The adjusted $\mathrm{R}^{2}$ of $55.6 \%$ indicates that should the regression equation accommodate further explanatory variable(s), there would be a significant level of relationship among the variables. The $\mathrm{t}$-calculated value $=$ 
11.129, $\mathrm{p}=0.000$ is significant indicating that strategic marketing practices significantly influenced the environmental perception on customer-oriented service of the banks. To test the hypothesis, F-calculated value was compared against F-critical value. Since F-calculated value is greater than F-critical value $(\mathrm{F}$. cal. $=123.859>\mathrm{F}$. tab $=3.84)$, this shows that the overall model was significant. Hence, we reject the null hypothesis that states there is no relationship between strategic marketing practices and environmental perception on customer- oriented service in chosen Nigerian Banks and accept the alternative hypothesis.

As per the SPSS generated table 4.2 , the equation $\left(\mathrm{Y}=\beta_{0}+\beta_{1} \mathrm{SMP}+\varepsilon\right)$ becomes:

$$
\mathrm{Y}=0.568+0.792 \mathrm{SMP}+\varepsilon
$$

Where $\mathrm{Y}$ is the dependent variable (environmental perception of customer- oriented service) and SMP is the independent variable (strategic marketing practices).

According to the regression equation established, taking the independent variable into account (Strategic Marketing Practices) constant at zero, environmental perception of customer- oriented service will be 0.568 . The data findings analyzed also show that a unit increase in strategic marketing practices will lead to a 0.792 increase in environmental perception on customer- oriented service. This concludes that there is a significant positive impact of strategic marketing practices on environmental perception of customer- oriented service in banking industry in Nigeria. Presently, customers in Nigeria are capable of reaching their account anytime of the day even after they have closed from their work to withdraw money to carter for their pressing needs and wants.

The finding is consistent with the work of Wind \& Robertson (1983) who suggested the essential need to understand the marketing environment as the first step toward marketing strategy practice. The strategic decisions should take into account relevant marketing environment that includes competitive, economic, political, technological, legal, and regulatory and social forces surrounding the customer and affects the marketing mix. For any strategy to be effective, it should seek to fulfill both the needs and requirements of customers (the market conditions in which it is implemented), and to the resources and capabilities of the firm seeking to implement it. No matter how wonderfully crafted and articulated the strategy, if it is not focused on meeting the needs of customers it is doomed to be a failure.

\section{CONCLUSION}

From the research findings and analysis of the information obtained, which has been presented, the influence of strategic marketing practices on environmental perception of customer- oriented service indicates Beta of 
(0.792) at 0.05 significance level on Table 4.2. There is positive correlation but a stronger relationship between strategic marketing practices and environmental perception of customer- oriented service. Strategic marketing practice is a key determinant of effective customers' service delivery. The researchers' submission is that for Nigerian banking industry to survive in $21^{\text {st }}$ Century, position for customer service delivery and innovation are challenges facing the industry. Hence, it is vital for banks to embrace the concept of customer relationship management in their banking services. Kotler \& Armstrong (2012) opined that customer relationship management is the means of building and maintaining positive customer relationships by providing superior customer value as well as satisfaction. Position for customer service delivery entails the speed of delivery of service to customers, paying attention to customers, exhibiting maturity, and so on compared to competitors. This will lead to increased organizational performance, customers' retentions, and trust in Nigerian banking operations.

\section{RECOMMENDATIONS}

Adoption of strategic marketing practices has influenced the environmental perception of customer- oriented service. Based on this finding and many more, the following suggestions are recommended:

i. The commercial banks should embrace strategic marketing by being focused to adapt to changes, marketing of assets and capabilities and marketing of innovation for the growth and survival of the industry.

ii. Banks should be strategically positioned to optimize opportunities in the industry.

iii. Banks should invest in new technology in order to implement the right marketing strategies that are relevant in the modern world.

iv. Finally, there is a need for the Nigerian government to be consistently and strategically addressing some of the challenges confronting the banking sector such as inadequate ICT infrastructure, inadequate funding, power outages, and security that could make the sector unproductive.

\section{References:}

1. Abdalla H.K.(2001), An Empirical Investigation of the Strategic Marketing Practices of the Soft Drink Industry in Kenya, Unpublished MBA Thesis, University of Nairobi.

2. Agus, A., Baker, S., \& Kandampully, J. (2007). An exploratory study of service quality in the Malaysian public service sector.International Journal of quality and reliability management, 24(2), 177-190.

3. Akinyele, S.T. (2010). Significance of strategic marketing to enterprise performance: An empirical analysis of Nigerian oil and gas 
industry. Global Journal of Management and Business Research, 10(6), 60-77.

4. Akinyele, S.T. (2010). Strategic Marketing and Firms' Performance: A Study of Nigerian Oil and Gas Industry. Petroleum-Gas University of Ploiesti BULLETIN, LXII (4), 24-34.

5. Aliyu, M.S. \& Rosli, M. (2014). A pilot study on the relationship between some determinants of SME performance in Nigeria. Journal of Asian Scientific Research, 4(10), 597-602.

6. Amoako, N. \& Baah-Dartey, K. (2012). An analysis of the impact of strategic marketing on profitability of rural banks: A case study of Dangme Bank. International Journal of Marketing Studies, 4(2), 150156.

7. Anabila, P., \&Awunyo-Victor, D. (2012). Customer relationship management: A key to Ghana. International Journal of Marketing Studies, 5(2), 81-92.

8. Asubonteng, P., McCleary, K.J., \& Swan, J.E. (1996). SERVQUAL revisited: A critical review of service quality. The Journal of Services Marketing, 10 (6); 62(81). Retrieved on 3August 2013 from http://dx.doi.org/10.1108/08876049 610148602

9. Auka, D.O and Keraro, O.J. (2014). Strategic marketing and technological innovations and firm growth: The case of retail banking in Kenya. Sky Journal of Business Administration and Management, 2(8), $037-053$.

10. Barney, J. (1991). Developing competitive advantage: Long range planning, 22(5), 123-124.

11. Botha, G., and Van Renbury, A.C. (2010).Proposed business process improvement model with integrated customer experience management.South Africa Journal of Industrial engineering, 2(1), 4557.

12. Brown T.J, Churchil GA, and Peter, J. P (1992). Imperative for Improving Servince Quality. Sloane Manage. Rev., Summer, 29-38.

13. Christine, A. A. (2009). Strategic marketing practices adopted by General Motors East Africa Limited. Unpublished research project of School of Business, University of Nairobi.

14. Christopher, K. L. (2010). Strategic responses to changes in external environment by Supermarkets in Kenya. Unpublished research project of School of Business, University of Nairobi.

15. David, A. (2008). Strategic market management (5th Edition ed.). New York: John Willy \& sons.

16. Dibb \& Sally. (2006). Marketing planning (1st Edition ed.). Delma Thompson Learning. 
17. Durand, A., \& Bouzidi, L. (2008). The alignment between customer relationship management and IT strategy. A proposed Research Modes: Proceedings of the Southern Association for Information System Conference, March 13-15, USA, 1-6. Retrieved on 9 October 2011, from http://www.ebscohost.com

18. Ehigie, B.O. (2006). Correlates of customer loyalty to their bank: A case study in Nigeria. International Journal of Banking Marketing, 24(7), 494-508. Retrieved from http://dx.doi.org/10.1108/02652320610712102

19. Ehikhamenor, F. (2003). Information technology in Nigerian Banks: The limits of expectations. Information Technology for Development 10S Press, 2(1),13-21.

20. Ezeoha, A.E. (2005). Regulating internet banking in Nigeria: Problems and challenges-part. Journal of Internet Banking and Commerce, 10 (3), 2-4.

21. Farganis, J. (2011). Readings in social theory (6th ed.). New York, NY: McGraw-Hill.

22. Fatoki, O. (2015). The Financing options for new small and medium enterprises in South Africa. Mediterranean Journal of Social Sciences, 5(20), 748-755.

23. Ferrell, O.C., Maignan, I., (2001), "Corporate citizenship as a marketing instrument -concepts, evidence and research directions", European Journal of Marketing, 35 No.3/4, pp.418-57.

24. Folarin, B.A. (2000). Experimental design in psychology and education. Lagos: Ideal Press.

25. Gardner, D. M., Johnson, F., Lee, M. and Wilkinson, 1. (2000). "A Contingency Approach to Marketing High TechnologyP roducts", EuropeanJ ournal of Marketing vol. 34: 9/10, pp. 1053-1077.

26. Gichuki, L.M. and Ogollah, K. (2014). Factors influencing the choice of marketing strategies of commercial banks in Kenya. The Strategic Journal of Business and Change Management, 2 (24), 451-474.

27. Greenhalgh, T., Robert, G., Macfarlane, F., Bate, P. \& Kyriakidou, O. (2004). Diffusion of innovations in service organizations: systematic review and recommendations', The Milbank Quarterly, Vol. 82, no 4: 581-629.

28. Hambrick, D. (1983a). An empirical typology of mature industrialproduct environment. Academy for Management Journal, 26, 213-20.

29. Hambrick, D. (1983b). High profit strategies in mature capital goods industries: a contingency approach. Academy of Management Journal, 26(4), 687-707. 
30. Hambrick, D. (1983c). Some tests of the effectiveness and functional attributes of Miles and Snow's strategic types. Academy of Management Journal, 26, 5- 26.

31. Hofer, C. W. (1983). ROVA: A new measure for assessing organizational performance in Lamb(ed). Advances in Strategic Management, 2, JAI Press Inc.

32. Hooley, G.J., Greenley, G.E,, Cadogan, J.W. \& Fahy, J. (2005). The performance impact of marketing resources. Journal of Business Research, 58(1), 18-27. http://www.ebscohost.com.

33. Jaworski, B. J. (1988). Towards a Theory of Marketing Control: Environmental Context, Control Types, and Consequences. Journal of Marketing, 52 (3), 23-39.

34. Kheng, L.L., Mohamad, O., Ramayah, T. \& Mosahab, R. (2010). The impact of service quality: A study of banks in Penang, Malaysia. International Journal of Marketing Studies, 2(2), 57-66.Accessed on 8 April 2012 from http://www.ebscohost.com

35. Knapp, M. L. (1978). Social intercourse: from greeting to goodbye. Allyn and Bacon.

36. Koh, A. C. (1991). Relationships among organisational characteristics, marketing strategy and export performance. International Marketing Review, 8(3), 46-60.

37. Kothari, C.R. (2004). Research Methodology. Wishwa Prakashari, (2nd Ed).

38. Kotler, P. (1991) Marketing Management. Millenium Edition, Prentice-Hall, New Delhi.

39. Kumar, L., Malathy,D. \& Ganesh, L.S. (2011).The diffusion of ATM technology in Indian banking.Journal of Economic Studies, 38(4), 483-500. Retrieved

from http://dx.doi.org/10.1108/01443581111160905. Management Review, 49(3), 62-68. Retrieved on 5September 2012 from

40. Miller, G., \& Steinberg, M. (2005). Between people: A new analysis of interpersonal communication. Science Research Associates.

41. Munusamy, J., Chelliah, S., \& Mun, A.W. (2010). Service quality delivery and its impact on customer satisfaction in the banking sector in Malaysia. International Journal of Innovation, Management and technology,1(4), 398-404.Retrieved on 28 September 2013 from http:///www.ebscohost.com

42. Mutambuki, M.K. and Orwa, B.H. (2014). Marketing Strategies of Commercial Fish Farming under Economic Stimulus Programme (ESP) in Kenya: An Empirical Study of Kitui County. International Journal of Humanities and Social Science, 4(8), 111-121 
43. Neuman, W.L. (2000). Social Research Methods: Qualitative and Quantitative Approaches. Boston: Allyn and Bacon Publishers.

44. Nunnally, J. (1978). Psychometric Theory, ( $2^{\text {nd }}$ ed.). New York: McGraw-Hill.

45. Ogunleye, G.A. (2005). Regulatory challenges in a consolidated Nigeria banking system, NDCI Quarterly Review, 11(1), 6

46. Okoe, A. F., Ajei, J.S., \& Osarenkhoe (2013). Service quality in the banking sector in Service quality in the banking sector in Ghana. International Journal of Marketing Studies, 5(2), 81-92.

47. Olatunji, O.C. \& Adekola, D.R. (2017). The roles of Auditors in fraud detection and prevention in Nigeria deposit money banks:Evidence from South West. European Scientific Journal, 13(31), 290-306

48. Oladejo, M.O,.\& Oladipupo, A. (2011). Capital regulation and performance of the Nigerian : Need for review. Journal of Emerging Trends in Economics and Management Sciences,2(3), 215-224.

49. Olarewaju, A.A., \& Folarin, E.A. (2012). Impacts of external environment on organizational performance in the food and beverage industry in Nigeria. British Journal of Arts and Social Sciences, 6(2), 194-201. Retrieved on 15 September 2013 from http://www.bjournal.co.uk/BJSS.aspx organizational survival and customer loyalty in Ghana's banking industry. International Journal of marketing studies, 5(1), 107-117.

50. Onyabe, J.M., Okparachi, J., Nyor, T., Yahaya, O.A., \& Ahmed, M. (2018). Effect of Auditor Committee Tenure on financial reporting quality of listed deposit money banks in Nigeria. European Scientific Journal. 14(4), 1857-2431.

51. Osuagwu, L. (2001). An evaluation of the marketing strategies of Nigerian insurance companies, Academy of Marketing Studies Journal, 5(2), 17-30.

52. Parasuraman, A., Zeithaml, V.A., \& Berry, L.L. (1988). SERVQUAL: A multiple-item scale for measuring consumer perceptions of service quality. Journal of Retailing, 64(1),Spring, 1240. Retrieved on $5^{\text {th }}$ September 2012 from http://www.ebsco host.com

53. Porter, M. E (1980), Competitive Strategy: Techniques for Analyzing Industries and Competitors: New York: Free Press, public, private and public sector banks in Odisa. Business Perspectives and Research, research, Journal of Marketing Research, 47, 12- 25.

54. Rogers, E.M. (1995). Diffusion of Innovations, 4th ed., The Free Press, New York.

55. Soludo, C.C. (2004). Consolidating the Nigerian banking industry to meet the development challenges of the $21^{\text {st }}$ Century. Being an 
address delivered to the special meeting of the Bankers' Committee at the CBN Headquarter, Abuja, Nigeria.

56. Srinivasan, R., Rangaswamy, A., \& Lilien, G. (2005). "Turning Adversity into Advantage: Does Proactive Marketing during a Recession Pay Off?" International Journal of Research in Marketing, Vol. 22.

57. Swar, B., \& Sahoo, P. (2012). Determinants effective service delivery: A study of selected

58. Swati, T. (2013). Awareness of customers on service quality of public sector banks in

59. Ulwick, A.W., \& Bettencourt, L.A. 2008). Given customers a fair hearing.MIT Sloan Varanasi. Advances in Management, 6(6), 45-50. Retrieved on 5September 2013 from http://www.ebscohost.com.

60. Trochim, W. M. K. (2006). Introduction to Validity. Social Research Methods, retrieved from www.socialresearchmethods.net/kb/introval.php, September 9, 2010.

61. Waweru, A. N. (2011). Extent to which strategic marketing practices are applied by Non Governmental Organisations in Nairobi, Kenya. Unpublished research project of School of Business, University of Nairobi.

62. Wind, Y., \& Robertson, T.S., (1983). Marketing strategy: New directions for theory and

63. Woodward, R. (2004). Technological expansion: The interaction between diversification strategy and organization capacity, Journal of Management Studies, 33(3), 701-712.

64. Wright, S. (2005), "The CI marketing interface", Journal of Competitive Intelligence and Management, 3 (2), 3-7

65. Zhang, P. (2000). "The effects of animation on information seeking performance on the world wide web: securing attention of interfering with primary tasks?" Journal of the Association for Information Systems, 1 (1) 1-28. 